\title{
Ontogeny of Hepatic Bile Acid Conjugation in the Rat
}

\author{
FREDERICK J. SUCHY, SUSAN M. COURCHENE, AND WILLIAM F. BALISTRERI \\ Division of Pediatric Gastroenterology and Nutrition, Department of Pediatrics, University of Cincinnati College \\ of Medicine, and Children's Hospital Research Foundation, Cincinnati, Ohio 45229
}

\begin{abstract}
We studied the postnatal development of hepatic bile acid conjugation in the rat. Overall conjugating activity (homogenate assay) and the activity of the individual enzymes involved in the two step conjugation reaction (coenzyme A-bile acid thioester formation by microsomal cholyl-CoA ligase and amino acid transfer to this intermediate mediated by cytosolic cholyl-CoA:taurine $\mathrm{N}$-acyltransferase were measured on days $1,7,14,21$, and 56 of life. Cholic acid conjugation was significantly lower in the suckling rat on days 1,7 , and 14 compared to the adult rat on day 56. At weaning (21 days) there was a marked increase in homogenate activity to a level higher than at 56 days. This peak in conjugating activity could be precociously induced on day 14 by cortisone acetate injection on days 10 through 13. Both cholyl-CoA ligase and cholylCoA:taurine $\mathrm{N}$-acyltransferase activities were significantly lower during the first 14 days of life in comparison with 56 days. At 21 days of age there was a sharp increase in cholyl-CoA ligase activity to 1.5 times the activity in the adult; however, cholyl-CoA:taurine $\mathbf{N}$-acyltransferase activity remained less than half of that found in the adult. We conclude that 1) cholic acid conjugation, as assessed by determination of either total conjugating activity or by the individual enzymatic steps, is decreased in the suckling rat; 2) the peak in conjugating activity noted at weaning may be mediated by the hormonal milieu, and 3) cholylCoA ligase activity closely parallels the increase in total activity and appears to be rate-limiting during development. (Pediatr Res 19: 97-101, 1985)
\end{abstract}

\section{Abbreviations}

DCPIP, 2,6-dichlorophenolindophenol

PES, phenazine ethylsulfate

MOPS, 3-[N-morpholino]propane-sulfonic acid

HEPES, N-2-hydroxyethylpiperazine-N'-2-ethanesulfonic acid

Bile acids are conjugated in the liver with the amino acids taurine or glycine prior to biliary excretion (5). The microsomal enzyme cholyl-CoA ligase initiates this process with formation

Received April 25, 1984; accepted August 14, 1984.

Correspondence to Frederick J. Suchy, M.D., Division of Gastroenterology and Nutrition, Children's Hospital Research Foundation, Elland and Bethesda Avenues, Cincinnati, OH 45229.

This work was supported in part by NIH grant HD 16907-01, a Trustee Grant from Children's Hospital Research Foundation, and grants from the Association of Volunteers and the March of Dimes Birth Defects Foundation.

This study has been published in abstract form (Suchy FJ, Courchene SM, Balistreri WF Hepatology 2:727a, 1982, Pediatr Res 17:202a, 1983). of a bile acid-coenzyme A thioester. Bile acid-CoA:amino acid $\mathrm{N}$-acyltransferase then catalyzes the reaction of this intermediate in cytosol with taurine or glycine to form the final conjugated product (15). Conjugation lowers the $\mathrm{pKa}$ of bile acids and thus ensures that they are largely ion...ed at the $\mathrm{pH}$ range normally found in the intestinal lumen (25). Ionized conjugates are poorly absorbed by passive mechanisms in the upper small intestine and therefore remain available for micelle formation and solubilization of dietary lipid. An enterohepatic circulation then occurs through preferential active transport of conjugated bile acids by ileum and liver $(17,23)$. A recent study suggests that conjugation may be a rate-limiting step in bile secretion (35). Conjugation, particularly of mono- and dihydroxy bile acids, may also decrease the potential toxicity of these compounds to the intestinal brush border and to the hepatocyte $(7,27)$.

At birth the enterohepatic circulation of bile acids is not fully developed. Bile acid synthesis is decreased (33) and immaturity of synthetic pathways may lead to the production of unusual bile acid species (28). The circulating pool of bile acids is low and as a result intestinal concentrations may be inadequate for optimal fat digestion (34). Active transport of bile acids by both liver and gut is markedly decreased in comparison with the adult $(19,29)$. Previous studies indicate that bile acid conjugation is also immature at birth in the rat and hamster; there is, however, little information about the ontogeny of conjugation or the specific enzymes involved in this process $(4,14)$. In this study we show that overall bile acid conjugation and the activity of these enzymes were markedly decreased in the suckling rat. There was a characteristic pattern of development for each enzyme which could be related to overall bile acid conjugation and which correlated with known changes in the enterohepatic circulation of bile acids in the suckling and weanling rat.

\section{MATERIALS AND METHODS}

Animals. Pregnant Sprague-Dawley rats were obtained from Charles River Breeding Laboratories (Wilmington, MA) and allowed to deliver in our animal quarters for studies of 1 - and 7 day-old pups. Older (suckling and weanling) rats were obtained from the same source along with their dams at least 1 wk prior to study. Rats were housed in a temperature-controlled room at $22^{\circ} \mathrm{C}$ with alternating 12 -h light-dark cycles. Dams and weanlings were maintained on Purina Rat Chow (St. Louis, MO) and water ad libitum. All animals were sacrificed by cervical dislocation.

Reagents. The chemicals used in this study were: [carboxyl${ }^{14} \mathrm{C}$-cholic acid $(40-60 \mathrm{mCi} / \mathrm{mmol}$; greater than $98 \%$ pure by thin layer chromatography) from New England Nuclear, Boston, MA; sodium cholate from Calbiochem-Behring, Los Angeles CA; taurine, defatted bovine serum albumin, DCPIP, PES, nicotinamide, MOPS, and HEPES from Sigma Chemical Corp., St. Louis, MO; adenosine triphosphate, Coenzyme A lithium, Cho- 
lyl-CoA from P.L. Biochemical, Inc., Milwaukee WI; and InstaGel from Parkard, Downers Grove, IL. For thin layer chromatography, precoated Silica Gel $\mathrm{G}$ glass plates, layer thickness $250 \mu$, were obtained from Analtech, Inc. Newark, DE. All other reagents used were commercially available and of analytical grade.

Analytical assays. Protein (21), NADPH-cytochrome C reductase (26), and succinate-cytochrome $C$ reductase (31) were determined according to standard methods.

The homogenate assay for bile acid conjugates was modified slightly from the method of Lim and Jordan (18). One gram of liver (tissue was pooled from suckling animals) was homogenized in $4 \mathrm{ml}$ of ice-cold $250 \mathrm{mM}$ sucrose, $5 \mathrm{mM}$ Tris- $\mathrm{HCl}$ buffer, $\mathrm{pH}$ 7.4 with $1 \mathrm{mM}$ disodium EDTA using 10 up and down strokes at $400 \mathrm{rpm}$ of a Potter-Elvehjem tissue homogenizer. Ten milligrams of homogenate protein were added to a reaction mixture containing $2.5 \mu \mathrm{Ci}$ of [carboxyl- ${ }^{14} \mathrm{C}$-]-cholic acid, $0.5 \mathrm{mM}$ sodium cholate, $5 \mathrm{mM}$ taurine, $17 \mathrm{mM}$ nicotinamide, $0.65 \mathrm{mM} \mathrm{MgCl}$, $0.75 \mathrm{mM}$ EDTA, $0.63 \mathrm{mM}$ ATP, $0.12 \mathrm{M} \mathrm{KH}_{2} \mathrm{PO}_{4} / 0.12 \mathrm{M} \mathrm{K}_{2} \mathrm{H}$ $\mathrm{PO}_{4}(\mathrm{pH} 7.4)$ in a total volume of $3 \mathrm{ml}$. Samples were incubated in duplicate at $37^{\circ} \mathrm{C}$ for $30 \mathrm{~min}$ in a shaking water bath. A tube containing the same reagents plus boiled homogenate served as a blank. The reaction was stopped by freezing each tube in acetone and dry ice. Bile acids were extracted three times with $0.1 \% \mathrm{NH}_{4} \mathrm{OH}$ in ethanol at $90^{\circ} \mathrm{C}$. Supernatants were pooled, evaporated to dryness under nitrogen, and resuspended in 0.4 $\mathrm{ml}$ of chloroform/methanol (2:1). An aliquot of each sample was applied to a $250 \mu$ Silica Gel G TLC plate and developed in a solvent system containing chloroform/methanol/acetic acid/ water (65:24:15:9) (3). Standards were visualized in iodine vapor and bands corresponding to standards and intermediate zones were scraped into scintillation vials. Bile acids were eluted from the Silica Gel by addition of $3 \mathrm{ml}$ of ethanol. Ten milliliters of scintillation fluid (Insta-Gel) were added to each vial and the samples were counted in a Beckman LS-7500 scintillation counter with quenching corrected by an external standard ratio technique. $\left[{ }^{14} \mathrm{C}\right]$-taurocholate formed from the initial $\left[{ }^{14} \mathrm{C}\right]$-cholic acid was determined after subtraction of the blank. Conjugating activity was expressed per minute and per milligram of homogenate protein. Taurine conjugates comprised greater than $95 \%$ of the conjugates formed at every age. In preliminary studies the rate of product formation was linear for $60 \mathrm{~min}$.

Total bile acid conjugating activity was also measured on day 14 after pups received subcutaneous injections with a pharmacological dose of cortisone acetate $(10 \mathrm{mg} / 100 \mathrm{~g}$ body weight) on days 10 through 13 . Vehicle-injected litter mates served as controls. Corticosteroids have been used in previous studies to induce developmental changes in liver and intestinal enzymes $(9,12)$.

Cytosolic and microsomal fractions were prepared for the enzyme assays by homogenizing $2 \mathrm{~g}$ of liver in $12 \mathrm{ml}$ of ice-cold $250 \mathrm{mM}$ sucrose, $5 \mathrm{mM}$ MOPS buffer (pH 7.4) using 10 up and down strokes of a Potter-Elvehjem tissue homogenizer driven at $400 \mathrm{rpm}$. The homogenate was centrifuged at $12,000 \times g$ for 10 min at $4^{\circ} \mathrm{C}$ in a Sorvall RC2-B centrifuge. An aliquot of the supernatant was further centrifuged at $245,000 \times g$ for $70 \mathrm{~min}$ in a Beckman L8-55 ultracentrifuge. The $245,000-\mathrm{g}$ supernatant was used for the determination of cholyl-CoA:taurine N-acyltransferase activity; the microsomal pellet was resuspended in $1 \mathrm{ml}$ of the original buffer for determination of cholyl-CoA ligase activity. Protein and the intracellular enzymes, NADPH cytochrome $C$ reductase and succinate cytochrome $C$ reductase, were measured in all fractions prepared from two experiments each at 7 and 56 days to demonstrate comparable recovery and enrichment of microsomes in developing and mature rats.

Cholyl-CoA ligase was measured by the method of Polokoff and Bell (22) as modified by Killenoerg (15); $0.25 \mathrm{mg}$ of microsomal protein were added to a reaction mixture containing 5 mM ATP, $5 \mathrm{mM} \mathrm{MgCl}_{2}, 0.2 \mathrm{mM}$ cholic acid, $0.2 \mathrm{mM}$ Coenzyme A, $50 \mathrm{mM} \mathrm{NaF}, 100 \mathrm{mM}$ sodium phosphate, $\mathrm{pH} 7.5$, and 5-10 $\times 10^{4} \mathrm{cpm}$ of [carboxyl- ${ }^{14} \mathrm{C}$ ]-cholic acid which had been preequilibrated at $37^{\circ} \mathrm{C}$. Samples were incubated in duplicate in a shaking water bath for $5 \mathrm{~min}$. Controls consisted of the reagents, minus microsomal protein, incubated at $37^{\circ} \mathrm{C}$ and the complete system incubated at $4^{\circ} \mathrm{C}$. The reactions were terminated by the addition of $0.5 \mathrm{ml}$ of ice-cold methanol. Test tubes were then left on ice for $5 \mathrm{~min}$, covered, and centrifuged to precipitate protein. An aliquot of supernatant $(0.7 \mathrm{ml})$ was added to $0.5 \mathrm{ml}$ of $6 \%(\mathrm{v} / \mathrm{v})$ perchloric acid. Bile acids were extracted from this mixture twice with $10 \mathrm{ml}$ of ethyl ether. Greater than $98 \%$ of unreacted bile acids were extracted with the ethyl ether while the ether-insoluble cholyl-CoA product remained in the aqueous phase (22). Ether residue was removed from each sample by suffusion with dry nitrogen gas for $20 \mathrm{~s}$. Aliquots were neutralized with $11.5 \mathrm{~N}$ ammonium hydroxide and counted in a scintillation counter. Blanks, in which microsomal protein was omitted or in which the reaction mixture was incubated at $4^{\circ} \mathrm{C}$, showed little or no product formation.

Cholyl-CoA:taurine $\mathrm{N}$-acyltransferase was measured by a continuous spectrophotometric method as described by Killenberg (16). In this assay amino acid dependent, enzymatic release of CoASH was measured by recording the rate of reduction of the blue dye DCPIP in the presence of PES. The reaction mixture contained $25 \mathrm{mM}$ HEPES buffer, $\mathrm{pH} 7.2,50 \mu \mathrm{M}$ cholyl-CoA, $50 \mu \mathrm{M}$ DCPIP, $20 \mu \mathrm{M}$ PES, $1 \mathrm{mg}$ of defatted bovine serum albumin, $20 \mathrm{mM}$ taurine, and 0.05 to $0.10 \mathrm{mg}$ of cytosolic protein in a final volume of $1 \mathrm{ml}$. All reagents except taurine were first filtered $(0.45 \mu$ Millipore filter $)$, mixed, and warmed to $30^{\circ} \mathrm{C}$ for $2 \mathrm{~min}$. Cytosolic protein was then added and after 1 min taurine or distilled water $(0.2 \mathrm{ml})$ was added with rapid mixing. The change in absorbance at $600 \mathrm{~nm}$ was measured at $30^{\circ} \mathrm{C}$ for $4 \mathrm{~min}$ on a Gilford 260 recording spectrophotometer. The rate of reaction was linear in excess of $4 \mathrm{~min}$ as long as the cytosolic protein was diluted to ensure a final rate of reduction less than $1.2 \mathrm{nmol} / \mathrm{min}$ as recommended by Killenberg (16). The specific activity of the enzyme (nmol $\mathrm{min}^{-1} \mathrm{mg}^{-1}$ protein) was calculated as the difference in the rate of loss of absorbance in the presence and absence of taurine. A control incubation was always run in parallel which contained the protein and reagents except for cholyl-CoA to correct for nonspecific reduction of DCPIP.

Statistics. Comparison of results between each age group was made using Student's $t$ test for unpaired data. All results are expressed as means $\pm \mathrm{SE}$.

\section{RESULTS}

Recovery of cell protein and intracellular marker enzymes. Liver homogenate, cytosol, and a relatively crude microsomal preparation were used for assays in this study. It was, therefore, important for interpretation of the data to ensure that the protein content in the various fractions and that the enrichment of intracellular marker enzymes were comparable for the adult and developing rat. The percent of total homogenate protein recovered in the cytosolic fraction was $27.9 \%$ for 56 day and $23.3 \%$ for 7 day animals (Table 1). The protein content of the microsomal fraction represented 8.9 and $6.8 \%$ of the homogenate total protein in 56 and 7 day rats, respectively.

Activities of the microsomal enzyme, NADPH cytochrome C reductase, and the mitochondrial enzyme, succinate cytochrome $\mathrm{C}$ reductase, were predictably lower in the 7-day-old pup. However, 31.9 and $26.7 \%$ of homogenate NADPH cytochrome C reductase activity were recovered in the microsomal fraction for the 56- and 7-day-old rats, respectively; microsomal fractions were enriched approximately 4 -fold in this enzyme at both ages. Recovery and relative specific activity in each fraction were also similar for succinate cytochrome $\mathrm{C}$ reductase; there was minimal contamination of the microsomes with this mitochondrial enzyme.

Ontogeny of hepatic bile acid conjugation homogenate as- 
Table 1. Recovery of cell protein and intracellular marker enzymes

\begin{tabular}{|c|c|c|c|c|c|c|c|c|c|c|}
\hline \multirow[b]{2}{*}{ Fraction } & \multicolumn{2}{|c|}{ Protein } & \multicolumn{4}{|c|}{ NADPH cytochrome $\mathrm{C}$ reductase } & \multicolumn{4}{|c|}{ Succinate cytochrome $\mathrm{C}$ reductase } \\
\hline & $\begin{array}{l}\text { Total } \\
\text { protein } \\
(\mathrm{mg})\end{array}$ & $\begin{array}{c}\% \\
\begin{array}{c}\text { Homogenate } \\
\text { protein }\end{array} \\
\end{array}$ & Activity & $\begin{array}{c}\text { Relative } \\
\text { specific } \\
\text { activity } v s \\
\text { homogenate }\end{array}$ & $\begin{array}{c}\text { Total } \\
\text { activity }\end{array}$ & $\begin{array}{c}\% \\
\text { Homogenate } \\
\text { activity }\end{array}$ & Activity & $\begin{array}{c}\text { Relative } \\
\text { specific } \\
\text { activity vs } \\
\text { homogenate }\end{array}$ & $\begin{array}{c}\text { Total } \\
\text { activity }\end{array}$ & $\begin{array}{c}\% \\
\text { Homogenate } \\
\text { activity } \\
\end{array}$ \\
\hline \multicolumn{11}{|l|}{56 Days } \\
\hline $\mathrm{H}$ & 398.05 & & 31.93 & & 12698.00 & & 87.20 & & 34693.54 & \\
\hline PI & 170.10 & 42.7 & 34.53 & 1.08 & 5885.20 & 46.4 & 166.87 & 1.91 & 28347.89 & 81.7 \\
\hline SI & 172.82 & 43.4 & 38.49 & 1.21 & 6667.17 & 52.5 & 10.77 & 0.12 & 1850.89 & 5.3 \\
\hline SII & 111.03 & 27.9 & 4.21 & 0.13 & 464.98 & 3.7 & 10.99 & 0.13 & 1222.24 & 3.5 \\
\hline PII & 35.35 & 8.9 & 115.25 & 3.61 & 4054.89 & 31.9 & 4.35 & 0.05 & 155.44 & 0.5 \\
\hline \multicolumn{11}{|l|}{7 Days } \\
\hline $\mathrm{H}$ & 369.85 & & 14.58 & & 5388.07 & & 67.27 & & 24901.97 & \\
\hline $\mathrm{PI}$ & 203.07 & 54.9 & 20.18 & 1.38 & 4091.88 & 75.9 & 92.21 & 1.37 & 18727.60 & 75.2 \\
\hline SI & 155.91 & 42.2 & 14.73 & 1.01 & 2273.83 & 42.2 & 8.39 & 0.12 & 1287.01 & 5.2 \\
\hline SII & 86.02 & 23.3 & 3.37 & 0.23 & 293.96 & 5.5 & 10.45 & 0.16 & 912.58 & 3.7 \\
\hline PII & 24.99 & 6.8 & 57.82 & 3.97 & 1437.07 & 26.7 & 3.59 & 0.05 & 89.91 & 0.4 \\
\hline
\end{tabular}

Values represent average of 2 experiments at each age. Enzyme activities in $\mathrm{nmol} \cdot \mathrm{min}^{-1} \mathrm{mg}$ protein ${ }^{-1}$.

Abbreviations: H, homogenate; PI, low speed pellet; SI, postmitochondrial supernatant; SII, cytosol; PII, microsomes.

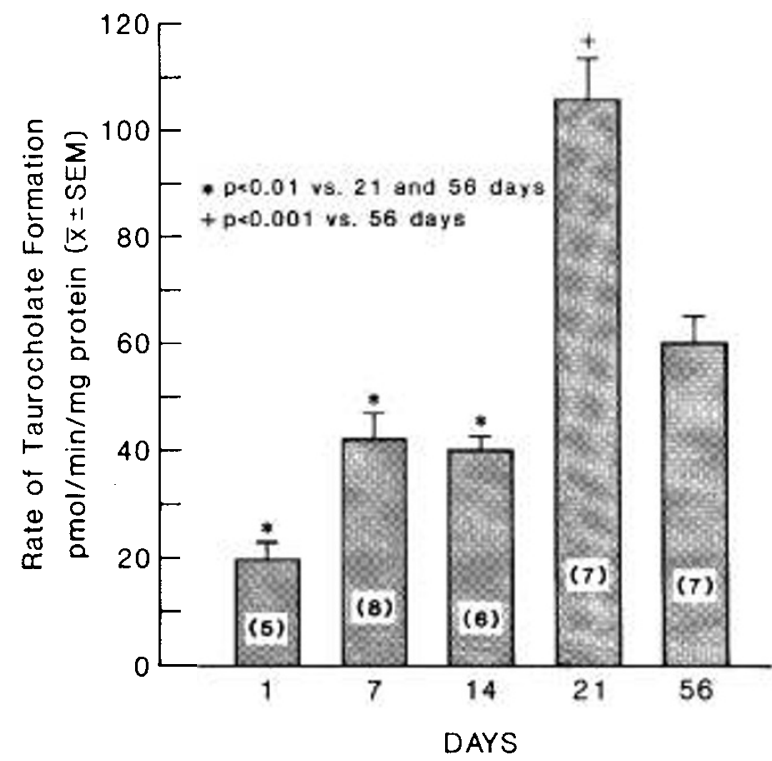

Fig. 1. Conjugation of cholic acid with taurine by liver homogenates. Parentheses within each bar refer to number of duplicate assays performed.

say. The overall ability of the liver to conjugate cholic acid with the amino acid taurine was examined with a homogenate assay at various ages between 1 and 56 days of age (Fig. 1). At birth bile acid conjugation was markedly decreased in comparison with the other age groups. Conjugating activity doubled by 7 days of age but little further change was noted through day 14 when conjugation was still significantly less than the adult. The ability to form conjugated cholic acid increased more than 2fold during the $3 \mathrm{rd}$ wk of life and in weanling rats, studied on day 21 , activity exceeded the level of the 56-day-old rat.

Effect of cortisone acetate treatment on hepatic bile acid conjugation. Injection of 10-day-old rats with cortisone acetate for 4 consecutive days was able to induce a premature increase in overall bile acid conjugating activity (Fig. 2). Formation of bile acid conjugates by liver homogenates from steroid-treated animals was significantly higher on day 14 than in normal pups or in vehicle-injected litter mates, but not significantly different from that of weanling rats on day 21 . Activity in vehicle-injected animals was also significantly higher than normal pups probably as a result of the stress involved with handling and injection.

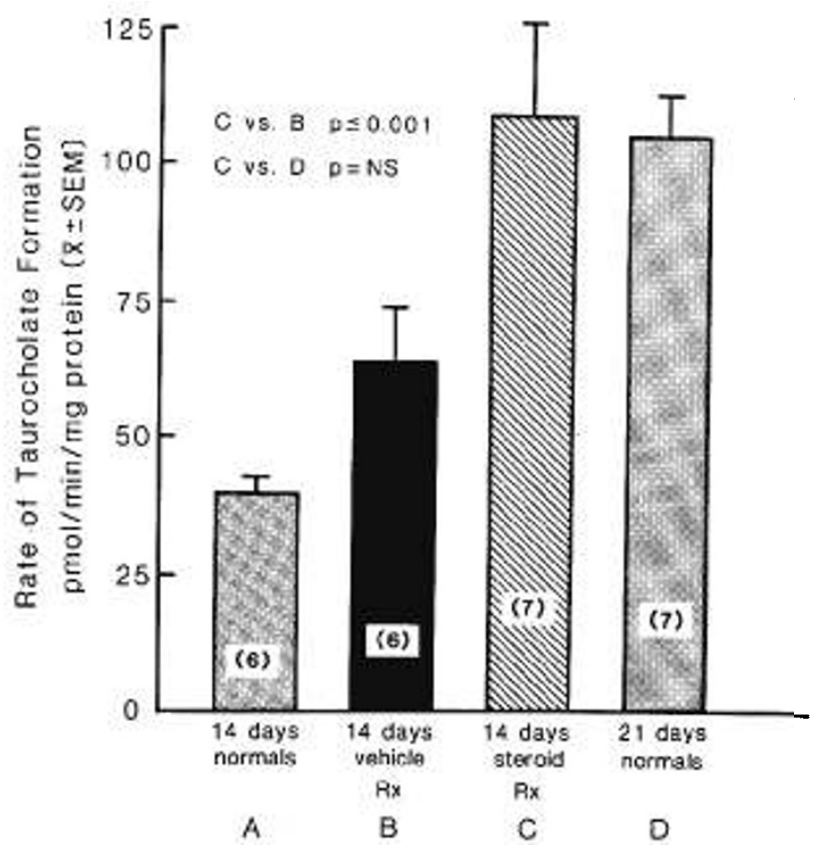

Fig. 2. Effect of cortisone acetate treatment on development of cholic acid conjugation. Parentheses within each bar refer to number of duplicate assays performed.

Bile acid conjugating enzymes. On the 1st day of life formation of the activated coenzyme A-bile acid thioester by cholylCoA ligase was only $8 \%$ of adult activity (Fig. 3). Also transfer of taurine to this intermediate by cholyl CoA:taurine $\mathrm{N}$-acyltransferase was $10 \%$ of that seen in the 56-day-old rat (Fig. 4). Both enzymes increased several-fold during the suckling period but at 14 days of age activity remained far less than that of the adult animal. The activity of the ligase sharply increased at weaning to 1.5 times the level of the adult. In contrast, transferase activity at 21 days remained less than half of that found in the adult.

\section{DISCUSSION}

Bile acid conjugates have been detected in meconium of human fetuses as early as wk 14 of gestation and in liver of rats as early as day 15 of gestation. These bile acid conjugates may reflect both endogenous synthesis by the fetal liver and to a lesser 


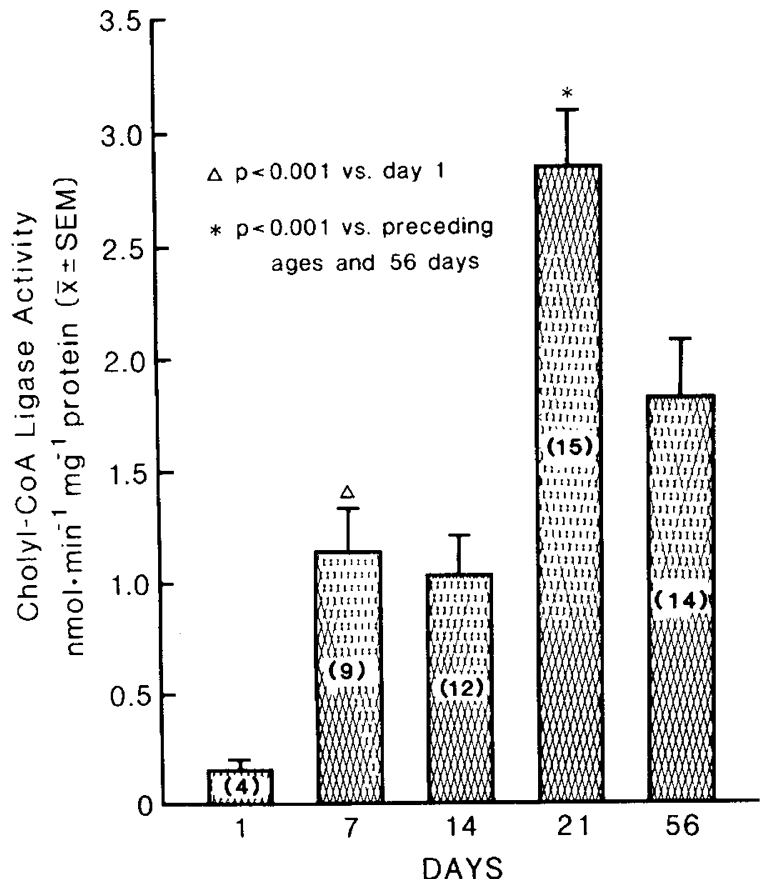

Fig. 3. Development of cholyl-CoA ligase activity. Parentheses within each bar refer to number of duplicate assays performed on separate liver microsomal preparations.

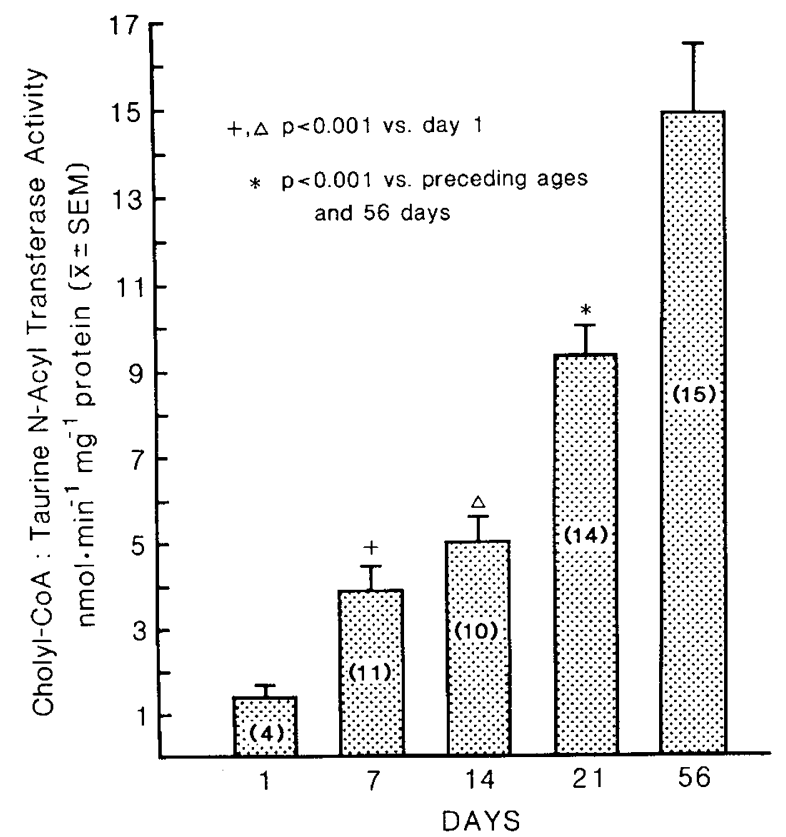

Fig. 4. Development of cholyl-CoA:taurine N-acyltransferase activity. Parentheses within each bar refer to number of duplicate assays performed on separate cytosolic preparations.

extent transplacental acquisition from maternal serum $(2,20)$. Recent studies using liver explants from human and rat fetuses confirm that bile acids are conjugated by the fetal liver $(8,10)$. Other studies have shown that glucocorticoids are able to increase and to maintain bile acid conjugation in culture of fetal rat hepatocytes (8). Danielsson and Rutter (4) were first to demonstrate that bile acid conjugation in liver homogenates from fetal and neonatal rats was much lower than in the adult. Jordan and Killenberg (14) later showed that the enzymes which mediate bile acid conjugation, cholyl-CoA ligase and cholyl-CoA:amino acid $\mathrm{N}$-acyltransferase, were decreased in the fetal and neonatal hamster liver and that both enzymes increased in parallel postnatally.
Our data confirm that bile acid conjugation, as determined by a homogenate assay, was decreased during the neonatal and suckling period in the rat. This assay should reflect the net contribution of each of the enzymatic steps involved in bile acid conjugation and therefore provided a framework for the analysis of these enzymes during development. Conjugating activity increased progressively during early life and was actually higher at weaning than in the adult. This developmental change was similar to that observed for the activity of several enzymes such as intestinal sucrase and hepatic alanine aminotransferase $(6$, 11). The timing suggested to us that the rate of maturation of bile acid conjugation may be related to the increase in serum corticosterone levels which occurs during the $3 \mathrm{rd} \mathrm{wk}$ of life in the rat. A cluster of other hepatic enzymes which are influenced by this hormonal change has been described by Greengard (9). Our results are in agreement with these studies since we were able to precociously induce bile acid conjugating activity with exogenous corticosteroids.

Activity of cholyl-CoA ligase, which forms the activated coenzyme A-bile acid thioester, has been localized primarily to the microsomal fraction of the hepatocyte $(15,18)$. Cholyl$\mathrm{CoA}$ :taurine $\mathrm{N}$-acyltransferase activity resides in the soluble portion of the cell $(15,18)$. We took great care to ensure that our microsomal preparations from the developing and mature rats were comparable. Several authors have cautioned that microsomes from developing rat liver may not vesiculate during tissue homogenization and therefore would pellet during the initial low speed centrifugation (24). In our study the initial centrifugation was performed at a lower rate than that used by Jordan and Killenberg. This resulted in similar microsomal but not increased mitochondrial enrichment at each age. We therefore believe that the marked age-related changes in enzyme activities described in this study cannot be explained simply on the basis of differences in cell fractionation.

The development of each of the specific enzymes involved in bile acid conjugation, cholyl-CoA ligase and cholyl-CoA:taurine $\mathrm{N}$-acyltransferase, paralleled the increase in total conjugating activity during the suckling period. Although both enzymes increased 5-fold during the suckling period, activity at 14 days was still far below the level of the adult. At weaning cholyl-CoA ligase activity exceeded that of the adult, while cholylCoA:taurine $\mathrm{N}$-acyltransferase remained significantly less. This pattern of development differs from that described in the hamster in which there was good correlation between the activity of both enzymes at all ages studied (14). It is clear from our data that cholyl-CoA ligase activity in the rat was higher at 21 days than adult activity and that this increase in enzyme activity corresponded to a similar surge in overall bile acid conjugation. These findings confirm the suggestion that the overall rate of bile acid conjugation is limited by the ligase activity $(16,32)$. The liver at 21 days was able to support a high rate of bile acid conjugation even though $\mathrm{N}$-acyltransferase activity was significantly less than the adult.

The effect of hormones on the ontogeny of individual enzymes involved in bile acid conjugation was not examined in this study. However, it is tempting to speculate that the high serum concentrations of corticosterone documented to be present during the 3 rd wk of life in the rat may have a greater or even a specific effect on cholyl-CoA ligase. The increase in overall conjugating activity at weaning may, in fact, be mediated by induction of ligase activity by corticosterone as part of the "late suckling" cluster of enzymes (9). The lack of a similar dramatic increase in transferase activity suggests that the enzyme may not require corticosteroids for its development. In a previous study we have shown that cortisone acetate treatment was not able to precociously induce another soluble transferase, bile acid sulfotransferase, when administered in the same pharmacological dose and at the same time as in the current study (1).

The biological significance of our findings must be considered in conjunction with other changes which are occurring in the enterohepatic circulation of bile acids during development. We 
doubt that significant quantities of unconjugated bile acids are excreted into the bile of suckling animals, although this question has not been examined with "state of the art" techniques in bile acid separation. We agree with the speculation of Jordan and Killenberg (14) that bile acid conjugation increases in concert with bile acid synthesis and pool size. There is, in fact, evidence for this sequence of events in the rat. Bile acid pool size per kilogram of body weight peaks after weaning (30). In addition ileal active transport exceeds (13) and hepatic bile acid uptake equals the levels of the adult at 21 days in the rat (unpublished observations). Genetic programing, the hormonal milieu, and dietary changes all are likely to contribute to the maturational changes in bile acid metabolism and transport which occur at weaning. Further studies are in order to assess the relative importance of each of these factors in the ontogeny of bile acid conjugation.

\section{REFERENCES}

1. Balistreri WF, Zimmer L, Suchy FJ 1984 Development of hepatic bile acid sulfotransferase. J Lipid Res 25:228

2. Bongiovanni AM 1965 Bile acid content of gallbladder of infants, children and adults. J Endocrinol Metab 25:678

3. Cass OW, Cowen AE, Hofmann AF, Coffin SB 1975 Thin-layer chromatographic separation of sulfated and nonsulfated lithocholic and their glycine and taurine conjugates. J Lipid Res 16:159

4. Danielsson H, Rutter WJ 1968 The metabolism of bile acids in the developing rat liver. Biochemistry 7:346

5. Danielsson H, Sjovall J 1975 Bile acid metabolism. Ann Rev Biochem 44:233

6. Franz JM, Know WE 1967 The effect of development and hydrocortisone on tryptophan oxygenase, formamidase, and tyrosine aminotransferase in the livers of young rats. Biochemistry $6: 3464$

7. Gracey M, Papadimitriou J, Burke V, Thomas J, Bower G 1973 Effects on small intestinal function and structure induced by feeding a deconjugated bile salt. Gut 14:519

8. Graham TO, Van Thiel DH, Little JM, Lester R 1979 Synthesis of taurocholate by rat fetal liver in organ culture: effects of cortisol in vitro. Am J Physiol 237:E177

9. Greengard O 1970 The developmental formation of enzymes in rat liver. In: Litwack G (ed) Biochemical Actions of Hormones, Vol. 1. Academic Press, New York, pp 53-87

10. Haber LR, Vaupshas V, Vitullo BB, Seermayer TA, DeBelle RC 1978 Bile acid conjugation in organ culture of human fetal liver. Gastroenterology $74: 1214$

11. Henning ST, Helman TA, Kretchmer N 1975 Studies in normal and precocious appearance of jejunal sucrase in suckling rats. Biol Neonate 26:249

12. Henning SJ, Sims JM 1979 Delineation of the glucocorticoid-sensitive period of intestinal development in the rat. Endocrinology 104:1158
13. Heubi JE, Suchy FJ, Rigney JL 1982 Ontogeny of intestinal bile salt transport in the rat. Gastroenterology 82:1083A

14. Jordan JT, Killenberg PG 1980 Development of enzymatic conjugation and sulfation of bile acids in hamster liver. Am J Physiol 238:G429

15. Killenberg PG 1978 Measurement and subcellular distribution of choloyl-CoA synthetase and bile acid-CoA:amino, acid $\mathrm{N}$-acyltransferase activities in rat liver. J Lipid Res 19:24

16. Killenberg PG 1981 Bile acid-CoA:amino acid N-acyltransferase. Methods Enzymol 77:308

17. Lack L, Weiner IM 1961 In vitro absorption of bile salts by small intestine of rats and guinea pigs. Am J Physiol 200:313

18. Lim WC, Jordan TW 1981 Subcellular distribution of hepatic bile acidconjugating enzymes. Biochem J 197:611

19. Little JM, Lester R 1980 Ontogenesis of intestinal bile salt absorption in the neonatal rat. Am J Physiol 239:G319

20. Little JM, Richey JE, Van Thiel DH, Lester R 1979 Taurocholate pool size and distribution in the fetal rat. J Clin Invest 63:1042

21. Lowry OH, Rosebrough NJ, Farr AL, Randall RJ 1951 Protein measurement with the folin phenol reagent. J Biol Chem 193:265

22. Polokoff MA, Bell RM 1977 Characterization of liver cholic acid coenzyme A ligase activity. J Biol Chem 252:1167

23. Reichen J, Paumgartner G 1976 Uptake of bile acids by perfused rat liver. Am J Physiol 231:734

24. Short CR, Kinden DA, Smith R 1976 Fetal and neonatal development of the microsomal monooxygenase system. Drug Metab Rev 5:1

25. Small DM 1971 The physical chemistry of cholanic acids. In: Nair PP Kritchevsky D (eds) The Bile Acids, Chemistry, Physiology and Metabolism, Vol 1. Plenum Press, New York, pp 249-356

26. Sottocasa GL, Kuylenstierna B, Ernster L, Bernstrand A 1967 An electrontransport system associated with the outer membrane of liver mitochondria. J Cell Biol 32:415

27. Stiehl A 1977 Disturbances of bile acid metabolism in cholestasis. Clin Gastroenterol 6:45

28. Strandvik B, Wikstrom SA 1982 Tetrahydroxylated bile acids in healthy human newborns. Eur J Clin Invest 12:301

29. Suchy FJ, Balistreri WF 1982 Uptake of taurocholate by hepatocytes isolated from developing rats. Pediatr Res 16:282

30. Suchy FJ, Heubi JE, Balistreri WF, Belknap WM 1981 The enterohepatic circulation of bile acids in suckling and weanling rats. Gastroenterology $80: 1351 \mathrm{~A}$

31. Tisdale DH 1967 Preparation and properties of succinic-cytochrome C reductase (complex II + III). Methods Enzymol 10:213

32. Vessey DA 1978 The biochemical basis for the conjugation of bile acids with either glycine or taurine. Biochem J 174:621

33. Watkins JB, Ingall D, Szczepanik P, Klein PD, Lester R 1973 Bile salt metabolism in the newborn, measurement of pool size and synthesis by stable isotope technique. N Engl J Med 288:431

34. Watkins JB, Lester R, Bliss CM, Donaldson RM 1974 Characterization of newborn fecal lipid. Pediatrics 53:511

35. Zouboulis-Vafiadis I, Dumont M, Erlinger S 1983 Conjugation is rate limiting in hepatic transport of ursodeoxycholate in the rat. Am J Physiol 243:G208 